DOI: 10.12731/wsd-2018-1-52-63

UDC 598.2(470.21)

\title{
FEATURES GASTOSTOMY AND CHARACTERISTICS OF NESTS OF THE GREAT TIT (PARUS MAJOR L.) AND THE COMMON REDSTART (PHOENICURUS PHOENICURUS L.) IN THE URBANIZED LANDSCAPE OF THE CITY OF MONCHEGORSK
}

\section{Koryakina T.N.}

The author made an analysis the composition and characteristics of nests of hole-nesting birds within the city of Monchegorsk and neighbouring areas: the great tit $(n=35)$ and the common redstart $(n=17)$ over a five-year period. The main parameters of the nests for the great tit are as follows: the height of $5.43 \pm 0.31 \mathrm{~cm}$, diameter of $14.52 \pm 0.42 \mathrm{~cm}$, weight $36.78 \pm 2.6 \mathrm{~g}$ and the common redstart: height of $7.2 \pm 0.6 \mathrm{~cm}$, diameter of $16.53 \pm 7.75 \mathrm{~cm}$, weight $61.82 \pm 5.84 \mathrm{~g}$. the Average starting date of the construction of the nest great tit at the first attempt of nesting 09 May $\pm 1,27$ (lim $_{\min }=$ April 24, lim $_{\max }=$ May 23; $n=27)$, a second attempt of nesting 24 June $_{1.79}\left(\right.$ (lim $_{\text {min }}=$ June 18, $\left.\lim _{\max }=J u l 11 ; n=8\right)$, the common redstart May $24 \pm 1.18\left(\lim _{\min }=\right.$ May 15, lim $_{\max }=$ June 06; $n=17)$. The predominant tree species for settlement nest-boxes and built nests of hole-nesting birds is the subarctic birch (Betula subarctica Orlova). The highest number of nests of the great tit (28.5\%) are in the nest with the four components; the nest, consisting of 2 and 3 components are, respectively, $8.5 \%$ and $22.9 \%$ of the total number of nests. In the nests of the great tit the number of components ranges from 2 to 5, an average of $4.37 \pm 0.28$, the main ones are green moss and dog wool. The overwhelming number of nests of the common redstart consists of seven components (29.5\%), nests, containing four, five and six components, accounting for 17.6 percent; the number of components is in the range from 3 to 10, averaging $6 \pm 0.46$. The most typical components of the common redstart nests are grass sprouts, leaves, bark and trash. Shoots of grasses, leaves, bark and trash-based nest of the common redstart. These components are the traditional natural materials for nests listed bird species. As a specific anthropogenic components used by birds to build their nests, used: polyethylene, paper (cardboard), wool yarn, burlap, cotton, polyester. The percentage of occurrence of an- 
thropogenic materials $34.3 \%$ for nests of the great tit and $52.9 \%$ for nests of the common redstart.

Keywords: nest; nest materials; natural and anthropogenic components; great tit (Parus major L.); common redstart (Phoenicurus phoenicurus L.).

\section{Introduction}

The great tit and the common redstart are widely spread species. The great tit is sedentary, common and numerous species of urban landscapes in the Murmansk region. The common redstart is a typical forest bird of the region that actively occupies the urban landscapes.

Hole-nesting birds are a convenient model species on which we can study various aspects of the breeding biology of birds [1]. Ecological peculiarities of representatives of the group allow them to be universal indicators of the environment. Hanging of nesting boxes in the city is a favorable condition for the formation of the control plots to study the effects of various factors on birds in different stages of breeding and for collecting a large enough initial material [2].

The main factors for successful realization of ecological niche for hole-nesting birds include features of the spatial structure of the city, existence of forage and nesting places. They form the population of hole-nesting birds in the city. Nesting bird life includes four main stages: building the nest, laying eggs, hatching and fledging. Nesting life of the birds includes four main stages: building the nest, egg laying, hatching and fledging. A comprehensive study of the breeding biology of birds includes the study of the construction of the nest and nesting material as an important stage of breeding period.

The goals of this work: 1 . To characterize nests of hole-nesting birds (weight, height, diameter); 2. to study the composition of the building material of the nests of the great tit and the common redstart in the urbanized environment of the city of Monchegorsk and the surrounding areas.

\section{Materials and methods}

Since 2010, a systematic work on the study of the breeding biology of hole-nesting birds has been conducted in the city of Monchegorsk. To do this, in different areas of the city nesting boxes were installed to attract hole-nesting birds to the city limits.

The material was collected in 2010-2014 within the city of Monchegorsk that located in the Murmansk region and situated in the Western mountainous part of the Kola Peninsula on the Western shore of the lake Imandra at the confluence in it of river Moncha to the north of the Arctic circle (N67 $55^{\prime}$, 
E57 $\left.32^{\prime}\right)$. The total number of apartment buildings in the city of Monchegorsk is 331 (a total area of 1207.6 thousand square meters or 23.6 square meters per resident). $97 \%$ of the total number of housing is placed in a stone two nine-storey apartment buildings, $3 \%$ in a two - storey wooden buildings. We can include in the old fund wooden low-rise buildings in the area Moncha and capital blocks housing mid-rise in the Central part of the city. Housing fund is characterized by a high level of engineering equipment $-100 \%$ of housing is provided with water supply, sewerage, heat supply, hot water supply [3]. The city-forming enterprise - the integrated plant "Severonikel", which produces copper-nickel production, it began to work in 1935. Since 1999 - a structural unit of JSC "Kola mining and metallurgical company".

Vegetative cover of the city of Monchegorsk is a combination of plots:

1) surviving remains of natural phytocenoses;

2) artificially cultivated plantings (squares, courtyards, potato gardens, etc.);

3) anthropogenic plant communities, occurring on its own, in areas destroyed by wild vegetation (vacant lots, coastal embankments, quarries, etc.).

Preserved massifs of old-growth forests are presented by of pine-sprucebirch, shrub-green-moss and lichen forests. On the banks of ponds wetland sparse Ledum and sphagnum pine forests, wetland motley grass birch forests with willow and alder, sedge and shrub-sphagnum bogs are represented. On the wet slopes there are dense thickets of tall willows with an admixture of pine, spruce and birch [4].

The birch, the spruce, the pine are the main tree species that are represented in the green areas of the city and where nesting boxes have been hung. For five years of research, 35 nests of the great tit and 17 nests of the common redstart have been analyzed. For the great tit, the nests of the first $(n=27)$ and the second $(n=8)$ nesting attempts for the season were investigated. To determine the size, weight and building material we used populated nests after fledging collected in the urban area of the city of Monchegorsk. The materials used by birds to build the nests were analyzed separately. The determination of the systematic affiliation of the plant components of the nests was carried out with varying degrees of accuracy, depending on the preservation of the materials. If it was impossible to determine in detail, only its type was indicated (for example, the stalks of cereals). Latin names are given in accordance with the annotated lists of vascular plants and vertebrate animals of the Lapland Reserve $[5 ; 6]$.

Air-dry nests (i.e. nests dried for 5-7 days in a dry room to a constant mass) and individual components of the nests were weighed on analytical scales with an accuracy of $0.01 \mathrm{~g}$. The nest dimensions were determined by a ruler with 
an accuracy $0,1 \mathrm{~cm}$, the height of the nests - by calipers with an accuracy of $0.1 \mathrm{~cm} \mathrm{[7].}$

The constant movement of the nestlings in the nest leads to rapid destruction of the nest and at the time of fledging the nesting structure is a more or less flat area if we speak about the great tit or a shapeless mass in the case of the common redstart. Therefore, not all nests managed to fully remove the parameters, especially this applies to the common redstart. For this species, the data for the whole nest (mass and compound of the nest components) are mainly presented.

\section{Results and discussion}

Over five years of observations, the nesting of four species of bird-hollows was recorded on the urban territory, which belong to the Order Passeriformes Passeriformes: the great tit (Parus major L.), the common redstart (Phoenicurus phoenicurus L.), the siberian tit (Parus cinctus Bodd), the european pied flycatcher (Ficedula hypoleuca Pall.). The main species are the great tit and the common redstart. They choose artificial nests on sites with increased anthropogenic load, including residential or public premises, crowded places and areas near roads. The choice of nesting sites is determined by different parameters of the plant community, which include the species composition of the tree stand, its spatial structure, degree of shading and humidity. These factors determine the food base for feeding nestlings, the temperature regime of the nest, its protection against adverse weather conditions [8]. The most readily birds colonized nesting boxes in preserved mature coniferous-deciduous residual natural phytocenoses with a significant admixture or predominance of the subarctic birch in the city and along the road along Lenin Avenue, where trees are planted. If the redstart prefers the outskirts of the city, then the great tit evenly occupies by artificial nests both in the center of the city (near living quarters, along motorways) and on the outskirts. As in other parts of its range, characteristic preference for the great tit for forest stands with a predominance of deciduous trees is observed $[9 ; 10]$.

A nest of the common redstart after withdrawal from the nest is a formless mass of leaves with other components. The lining is presented by the stems of cereals and feathers of a bird. The tray is displaced to one of the edges of the nest and is constructed from growth of grasses and lined with feathers. Clutch during incubation is in the tray and in the absence of birds in the nest, covered with feathers. In the skeleton, the bark of trees and rot make up an essential part of the nest composition - it is due to these components the common redstart nests are, as a rule, larger and heavier than the nests of the great tit (table 1, table 2). 
The predominant number of nests of the common redstart consists of seven components $(29.5 \%)$, nests consisting of four, five and six components have $17.6 \%$ to each type; the number of components is in the range from 3 to 10 , on average $6 \pm 0.46$.

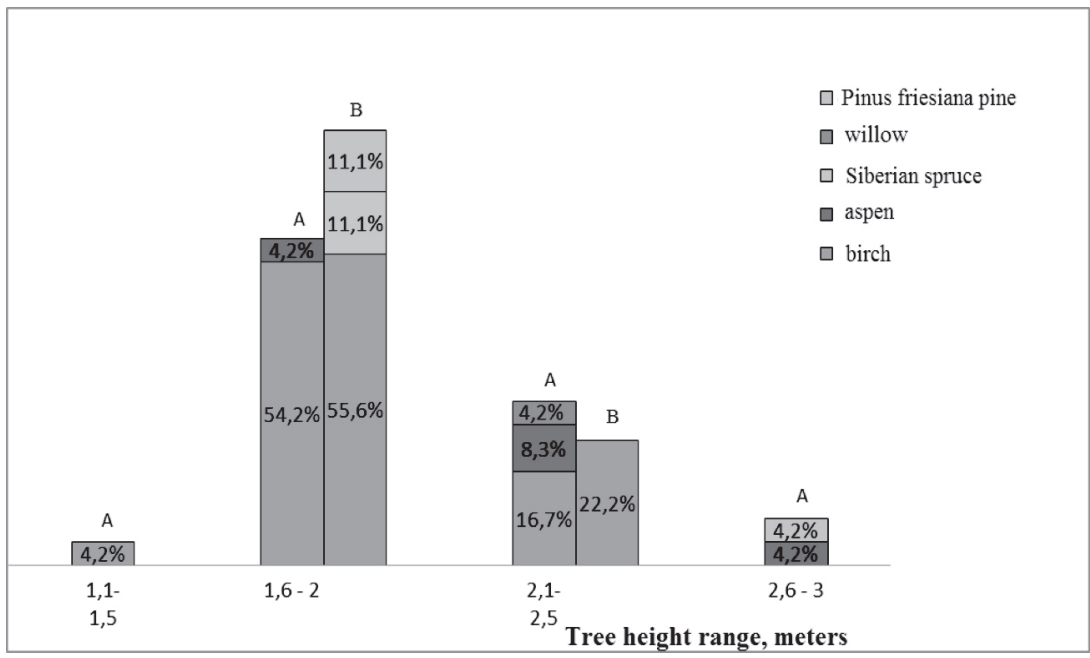

Fig. 1. The distribution of nests of the great tit (A) and the common redstart (B) according to the species and height of trees in the city of Monchegorsk and the surrounding areas

Table 1.

The size of the nests of the great tit and the common redstart in the city of Monchegorsk

\begin{tabular}{|c|c|c|c|c|c|c|}
\hline \multirow{2}{*}{ Parameter } & \multicolumn{3}{|c|}{ The great tit } & \multicolumn{3}{c|}{ The common redstart } \\
\cline { 2 - 7 } & $\frac{\mathrm{X} \pm m, \mathrm{~cm}}{\mathrm{Lim}}$ & $\sigma$ & $C V, \%$ & $\frac{\mathrm{X} \pm m, \mathrm{~cm}}{\mathrm{Lim}}$ & $\sigma$ & $C V, \%$ \\
\hline Diameter of a nest & $\frac{14.52 \pm 0.42}{10.4-18.3}$ & 2.35 & 16.18 & $\frac{16.53 \pm 1.75}{10.1-20.4}$ & 3.93 & 23.71 \\
\hline Diameter of a tray & $\frac{6.26 \pm 0.29}{4.47-10.4}$ & 1.35 & 21.57 & $\frac{7.81 \pm 0.88}{5.2-12}$ & 2.15 & 27.53 \\
\hline Height of a nest & $\frac{5.43 \pm 0.31}{1.9-8.55}$ & 1.78 & 32.78 & $\frac{7.2 \pm 0.6}{4.12-10.1}$ & 1.8 & 24.86 \\
\hline Depth of tray & $\frac{3.84 \pm 0.31}{1.8-6.1}$ & 1.37 & 35.68 & $\frac{3.85 \pm 0.34}{2.4-4.9}$ & 0.9 & 23.38 \\
\hline
\end{tabular}

Note. $X$ - arithmetic mean, $m$ - error of the mean, lim - minimum and maximum value of the characteristic, $\sigma$ - standard deviation, $\mathrm{CV}$ - coefficient of variation. 
Table 2.

The mass of the nests of the great tit and the common redstart in the city of Monchegorsk

\begin{tabular}{|c|c|c|c|c|c|c|}
\hline \multirow{2}{*}{ Parameter } & \multicolumn{3}{|c|}{ The great tit } & \multicolumn{2}{c|}{ The common redstart } \\
\cline { 2 - 7 } & $\frac{\mathrm{X} \pm m, \Gamma}{\mathrm{Lim}}$ & $\sigma$ & $C V, \%$ & $\frac{\mathrm{X} \pm m, \Gamma}{\mathrm{Lim}}$ & $\sigma$ & $C V, \%$ \\
\hline Weight of a frame & $\frac{21.5 \pm 2.1}{8.9-39.22}$ & 7.71 & 35.86 & ---- & ----- & ----- \\
\hline Weight of a tray & $\frac{12.35 \pm 1.3}{5.95-21.64}$ & 4.87 & 39.43 & ----- & ----- & ----- \\
\hline Weight of a nest & $\frac{36.78 \pm 2.6}{6.89-725.56}$ & 14.26 & 38.78 & $\frac{61.82 \pm 5.84}{18.06-119.45}$ & 23.34 & 37.75 \\
\hline
\end{tabular}

The largest number of nests of the great tit (28.5\%) falls on the nests with four components; the nests, consisting of 2 and 3 components, constitute, respectively, $8.5 \%$ and $22.9 \%$ of the total number of nests (Fig. 2). In the nests of the great tit, the number of components varies from 2 to 5 , an average of 4.37 \pm 0.28 (Table 3 ). The nest of the great tit is a rectangular "pressed" cake or a homogeneous mass; tray is in the center of the nest. In the city, the lining is usually represented by dog wool with small inclusions of anthropogenic material: thread and polyethylene. In the natural habitat the lining consists of the wool of wild animals (voles, lemmings, elk, hares, etc.). In the nests of tits, green moss, which is the base of the frame of the nest, almost always remains the main building material, because it is a good heat insulator and at the same time is soft enough for the subsequent change in the shape of the nest [11]. During the incubation of eggs (when the great tit leaves the nest), clutch is most often covered with wool and there is in the middle of the mass little heat-conducting springy green moss and wool. Such a method of preserving unhatched eggs allows tits to begin nesting before most other hollow-nesting birds [12]. According to our observations, the average date of the beginning of nesting for the great tit at the first nesting attempt is May $9 \pm 1.27\left(\lim _{\min }=\right.$ April 24, $\lim _{\max }=$ May 23, $\left.n=27\right)$, at the second nesting attempt is June $24 \pm 1.79\left(\lim _{\min }=18 \mathrm{June}, \lim _{\max }=\right.$ July 11 , $n=8)$, for the common redstart this date is May $24 \pm 1.18\left(\lim _{\min }=\right.$ May $15, \lim _{\text {max }}$ $=$ June $06, n=17)$. The nesting period for the great tit is 14 days, for the common redstart -8 days. The timing of the beginning of nesting is determined by spring temperatures, migration peculiarities (the great tit - sedentary species in the region, the common redstart - migrant species, flying to wintering to central Africa and to the south of the Arabian Peninsula), evolutionary adaptations for the choice of components. 
Table 3 .

The number of components in the nests of the great tit and the common redstart in the city of Monchegorsk

\begin{tabular}{|c|c|c|c|c|c|c|}
\hline \multirow{2}{*}{ Parametr } & \multicolumn{3}{|c|}{ The great tit } & \multicolumn{3}{|c|}{ The common redstart } \\
\cline { 2 - 7 } & $\frac{\mathrm{X} \pm m}{\mathrm{Lim}}$, & $\sigma$ & $C V, \%$ & $\frac{\mathrm{X} \pm m,}{\mathrm{Lim}}$ & $\sigma$ & $C V, \%$ \\
\hline Frame & $\frac{2.69 \pm 0.21}{1-6}$ & 1.21 & 44.98 & ----- & ----- & ----- \\
\hline Lining & $\frac{1.69 \pm 0.12}{1-4}$ & 0.68 & 40.24 & ---- & ----- & ---- \\
\hline The whole nest & $\frac{4.37 \pm 0.28}{2-9}$ & 1.61 & 36.84 & $\frac{6 \pm 0.46}{3-10}$ & 1.79 & 29.83 \\
\hline
\end{tabular}

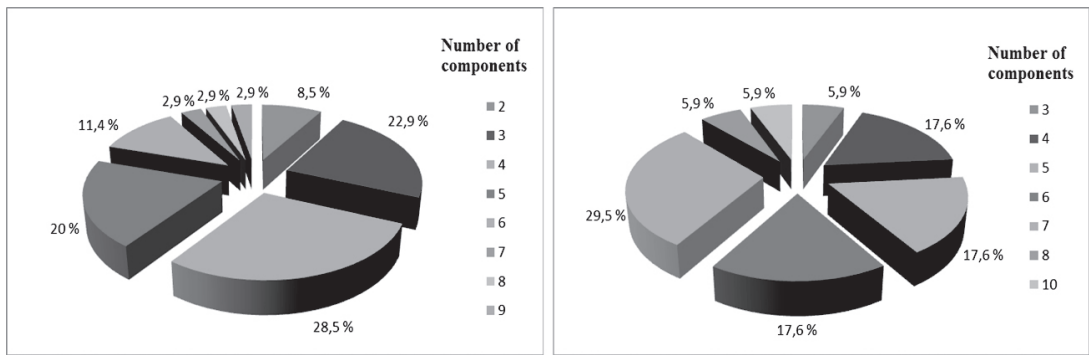

Fig. 2. The distribution of nests by number of components (\%) for the great tit (left) and for the common redstart (right).

From Table 4 it follows that the main components in the nest of the great tit are the green moss (Pleuroziy or Pleurozium Schreberi Pleurocium schreberi (Brid.) Mitt (= Hylocomiumschreberi (Brid.) DeNot.)), dog wool, stems of cereals, branches of trees and shrubs, horsetails: the horsetail field (Equisetum arvense L.) and the horsetail (Equisetum pratense Ehrh.). The stems of cereals are represented by several species, one of which is the northern agitus (Agrostis borealis C.Hartm.), the branches of trees and shrubs used by the birds in the construction of the nests are the subarctic birch (Betula subarctica Orlova), the siberian spruce (Picea obovata), the crowberry or the crowberry bisexual (Empetrum hermaphroditum Hagerup). If we speak about the great tit, lichen and needles can be assigned to single components.

In the nests of the common redstart, the main building material is distributed as follows: the stalks of cereals, leaves, rot, bark, wood. The basis of the building material of the common redstart nests are the last year's dry parts of plants and last year's fallen leaves. Basically, birch leaves of the subarctic 
(Betula subarctica Orlova), the willow (Salix sp.) and rowanberry of Gorodkov (Sorbus gorodkovii Pojark. (S. glabrata (Wimm. et Grab.)) were identified in the nest. In the nests in an insignificant amount, there is ground, which falls together with plant building material.

Table 4.

The frequency of occurrence (\%) of different types of materials in the nests of the great tit and the common redstart in the city of Monchegorsk, $\%$ of the total number of nests

\begin{tabular}{|c|c|c|c|c|c|c|}
\hline \multirow{2}{*}{ Parametr } & \multicolumn{3}{|c|}{ The great tit } & \multicolumn{3}{c|}{ The common redstart } \\
\cline { 2 - 8 } & nest & frame & lining & nest & frame & lining \\
\hline Branches of trees and shrubs & 40 & 40 & --- & 17.6 & 17.6 & --- \\
\hline Bark, wood & 2.8 & 2.8 & --- & 82.4 & 82.4 & --- \\
\hline Rot & ---- & ---- & ---- & 41.2 & 41.2 & --- \\
\hline Roots & 5.7 & 5.7 & ---- & 41.2 & 41.2 & --- \\
\hline Leaves & 31.4 & 29 & 2.4 & 100 & 93 & 7 \\
\hline The stems of cereals & 65.7 & 61 & 4.7 & 100 & 95.3 & 4.7 \\
\hline Horsetail & 37.1 & 35.5 & 1.6 & 17.6 & 17.6 & --- \\
\hline Needles & 22.9 & 22.9 & --- & 17.6 & 17.6 & --- \\
\hline Fruits, inflorescences & --- & ---- & --- & 5.9 & 5.9 & --- \\
\hline Moss & 100 & 91 & 9 & 58.2 & 58.2 & --- \\
\hline Feathers & 9.1 & ---- & 9.1 & 100 & 8 & 92 \\
\hline Wool & 100 & 11 & 89 & 5.9 & 5.9 & --- \\
\hline Skins of rodents & 8.6 & 8.6 & ---- & 23.5 & 23.5 & --- \\
\hline Anthropogenic materials & 34.3 & 24.7 & 9.6 & 52.9 & 52.9 & --- \\
\hline Lichen & 5.7 & 5.7 & ---- & 5.9 & 5.9 & --- \\
\hline
\end{tabular}

The components that predominate in the nests of birds are found in each nest: in the great tit they are green moss and wool, in the common redstart feathers, leaves, stems of cereals. Based on this, it can be concluded that exactly these are the main components for building a nest.

Many of the passerine birds use in the construction of their nests skins of mouse-shaped rodents dead in the nature. It should be noted that skins of rodents in nesting boxes in the study area are found only in 2012 for the entire study period. This is explained by the fact that on the eve, in 2011 the next maximum of their number was registered [13]. In the nests of birds were found skins of the Norwegian lemmings (Lemmus lemmus L.), the forest lemmings (Myopus schisticolor L.) and the red-gray vole (Clethrionomys rufocanus S.) in the urban periphery. 
Both species use anthropogenic components in construction of their nests. Specific anthropogenic components include: polyethylene, paper (carton), woolen threads, sackcloth, cotton wool, sintepon. A polyethylene rope $55 \mathrm{~cm}$ long was found in one nest of the common redstart. The percent of occurrence of anthropogenic materials is $34.3 \%$ for the nests of the great tit and $52.9 \%$ for the nests of the common redstart.

\section{Conclusion}

The high adaptive potential of hollow-nesting birds is mostly pronounced in the nesting phase. The nature of the construction and components of the nest are specific for each species and are determined, in the main, by the bird's way of life. The common redstart's nests are larger, heavier and more diverse in number of components than the nests of the great tit. Hollow-nesting birds in the city of Monchegorsk use in the construction of nests traditional, natural materials: loose, amenable to the seal components, and the flat details easily movable relative to each other. In the nests of the great tit, the main building material is green moss, which is used for building a frame, and wool for lining the tray. The frame of the common redstart nest consists of leaves, stems of cereals, branches, bark and rot, the tray is lined with feathers of a bird. Also, accomplished observations showed that within the city limits in addition to traditional natural components, birds actively use materials of anthropogenic origin in the lining and in the frame, that is an adaptation to urbanized landscape and changing environmental conditions.

\section{References}

1. Skrypnikova E.B. Osobennosti ekologii bol'shoy sinitsy kak fonovogo vida ornitokompleksov g. Voronezha [Features of the ecology of the Great Tit as a background species of the Ornithocomplexes of the city of Voronezh]. Sovremennye problemy nauki i obrazovaniya [Modern problems of science and education]. 2011. № 5. https://www.science-education.ru/en/article/view?id=4821

2. Lebedeva N.V. Ptitsy-duplognezdniki kak model'nye ob"ekty bioindikatsii [Birds-hollows as model objects of bioindication]. Ptitsy-duplognezdniki kak model'nye obekty $v$ reshenii problem populyatsionnoy ekologii i evolyutsii: materialy mezhdunarodnoy konferentsi [Birds-hollows as model objects in solving problems of population ecology and evolution: materials of the international conference]. M .: The number of scientific publications KMK, 2014, pp. 167-170.

3. Investitsionnyy pasport goroda Monchegorska [Investment passport of the city of Monchegorsk], 2013. http://minec.gov-murman.ru/files/invest_monch.pdf. 
4. Monitoring of the state of the natural environment of the Lapland State Natural Biosphere Reserve, as well as the territory adjacent to Severonickel, including Monchegorsk and its environs (the fifth stage): report on the contract with the Kola Mining and Metallurgical Company No. D-1089 / ed. V.Sh. Barkan. Monchegorsk, 2002. 134 p. Archive of the Lapland Reserve.

5. Berlina N.G. Sosudistye rasteniya Laplandskogo zapovednika (annotirovannyy spisok vidov) [Vascular Plants of the Lapland Reserve (Annotated List of Species)]. Flora i fauna zapovednikov [Flora and Fauna of Reserves]. Issue 64. M., 1997. $58 \mathrm{p}$.

6. Kataev G.D. Mlekopitayushchie. Fauna Laplandskogo zapovednika [Mammals. Fauna of the Lapland Reserve]. Flora i fauna zapovednikov [Flora and Fauna of Reserves]. Issue. 63. M., 1997, pp. 39-44.

7. Shubina Yu.E., Federyakina I.A., Lykov E.L. Razmery, massa i stroitel'nyy material gnezd chernogo drozda (Turdus Merula (Aves) v Lipetskoy i Kaliningradskoy oblastyakh [Dimensions, mass and building material of the nests of the blackbird (Turdus Merula (Aves) in the Lipetsk and Kaliningrad Regions)]. Bulletin of the Moscow Island of Naturalists, 2011. 2011. V. 116. Issue 6, pp. 48-53.

8. Molokanova Yu.P. Osobennosti ekologii gnezdovaniya penochek (Phylloscops) v Moskovskoy oblasti [Peculiarities of the Ecology of Nesting of Phylloscops in the Moscow Region]. Bulletin of MGOU. 2013. № 1, pp. 1-22.

9. Artemev A.V. Populyatsionnaya ekologiya bol'shoy sinitsy Parus major v taezhnykh lesakh Karelii. Ch. 1. Struktura naseleniya i osobennosti gnezdovaniya [Population ecology of the large titmouse Parus major in the taiga forests of Karelia. Part 1. The structure of the population and the features of nesting]. Uchenye zapiski Petrozavodskogo gosudarstvennogo universiteta [Scientific notes Petrozavodsk State University]. 2008. № 2 (92), pp. 31-43.

10. Zimin V.B. Materialy po gnezdovaniyu bol'shoy sinitsy (Parus Major L.) v Karelii [Materials on the nesting of the Great Tit (Parus Major L.) in Karelia]. Fauna i ekologiya ptits i mlekopitayushchikh taezhnogo Severo-Zapada SSSR [Fauna and ecology of birds and mammals of the taiga Northwest of the USSR]. Petrozavodsk, 1978, pp. 17-31.

11. Blagosklonov K.N. Gnezdovanie i privlechenie ptits $v$ sady i parki [Nesting and attracting birds to the gardens and parks]. Moscow: Izd-vo MGU, 1991. $251 \mathrm{p}$.

12. Bianki V.V., Shutova E.V. K ekologii bol'shoy sinitsy Parus major v Murmanskoy oblasti [To the ecology of the big titmouse Parus major in the Murmansk region]. Russkiy ornitologicheskiy zhurnal [Russian ornithological journal]. 2011. Volume 20. № 628, pp. 186-195. 
13. Kataev G.D. Monitoringovye issledovaniya fauny melkikh mlekopitayushchikh Micromammalia na Kol'skom poluostrove (Laplandskiy zapovednik) [Monitoring studies of the fauna of small mammals Micromammalia on the Kola Peninsula (Lapland Reserve)]. Ekologicheskie problemy severnykh regionov i puti ikh resheniya: materialy $V$ Vserossiyskoy nauchn. konf. s mezhdunar. uchastiem 23-27 iyunya 2014 g. Apatity. V 3 ch. Ch. 1. Institut problem promyshlennoy ekologii Severa KNTS RAN [Ecological Problems of the Northern Regions and Ways to Solve them: Materials of the V All-Russian Scientific Conference. Conf. with intern. Participation June 23-27, 2014 Apatity. At 3 o'clock Part 1. Institute of Problems of Industrial Ecology of the North KSC RAS]. Apatity: KSC RAS, 2014, pp. 151-155.

\section{Список литературы}

1. Скрыпникова Е.Б. Особенности экологии большой синицы как фонового вида орнитокомплексов г. Воронежа // Современные проблемы науки и образования. 2011. №5. https://www.science-education.ru/ru/article/ view?id=4821

2. Лебедева Н.В. Птицы-дуплогнёздники как модельные объекты биоиндикации // Птицы-дуплогнёздники как модельные объекты в решении проблем популяционной экологии и эволюции: материалы международной конференции. М.: Т-во научных изданий КМК, 2014. С. 167-170.

3. Инвестиционный паспорт города Мончегорска, 2013 [Электронный реcypc]. http://minec.gov-murman.ru/files/invest_monch.pdf.

4. Мониторинг состояния природной среды Лапландского государственного природного биосферного заповедника, а также территории, прилегающей к ОАО комбинат «Североникель», включая г. Мончегорск и его окрестности (пятый этап): отчет по договору с Кольской Горно-Металлургической компанией № Д-1089 / рук. и отв. исполнитель В.Ш. Баркан. Мончегорск, 2002. 134 с. Архив Лапландского заповедника.

5. Берлина Н.Г. Сосудистые растения Лапландского заповедника (аннотированный список видов) // Флора и фауна заповедников. Вып. 64. М., 1997. $58 \mathrm{c}$.

6. Катаев Г.Д. Млекопитающие. Фауна Лапландского заповедника // Флора и фауна заповедников. Вып. 63. М., 1997. С. 39-44.

7. Шубина Ю.Э., Федерякина И.А., Лыков Е.Л. Размеры, масса и строительный материал гнёзд черного дрозда (Turdus Merula (Aves) в Липецкой и Калининградской областях // Бюл. Моск. о-ва испытателей природы. Отд. биол. 2011. Т. 116. Вып. 6. С. 48-53. 
8. Молоканова Ю.П. Особенности экологии гнездования пеночек (Phylloscops) в Московской области // Электронный журнал «Вестник МГОУ». 2013. № 1. С. 1-22.

9. Артемьев А.В. Популяционная экология большой синицы Parus major в таёжных лесах Карелии. Ч. 1. Структура населения и особенности гнездования // Учёные записки Петрозаводского государственного университета. 2008. № 2 (92). C. 31-43.

10. Зимин В.Б. Материалы по гнездованию большой синицы (Parus Major L.) в Карелии // Фауна и экология птиц и млекопитающих таёжного Северо-Запада СССР. Петрозаводск, 1978. С. 17-31.

11. Благосклонов К.Н. Гнездование и привлечение птиц в сады и парки. М.: Изд-во МГУ, 1991. $251 \mathrm{c.}$

12. Бианки В.В., Шутова Е.В. К экологии большой синицы Parus major в Мурманской области // Русский орнитологический журнал. 2011. Том 20. Экспресс-выпуск 628. С. 186-195.

13. Катаев Г.Д. Мониторинговые исследования фауны мелких млекопитающих Micromammalia на Кольском полуострове (Лапландский заповедник) // Экологические проблемы северных регионов и пути их решения: материалы V Всероссийской научн. конф. с междунар. участием 23-27 июня 2014 г. Апатиты. В 3 ч. Ч. 1. Институт проблем промышленной экологии Севера КНЦ РАН. Апатиты: КНЦ РАН, 2014. С. 151-155.

\section{DATA ABOUT THE AUTHOR}

Koryakina Tatyana Nikolaevna, Graduate Student

Murmansk State Technical University

13, Sportivnaya Str., Murmansk, 183010, Russian Federation

o_umi@list.ru 